\title{
Research perspectives on the Arab-Israeli conflict: introduction to a symposium
}

\author{
JOSEPH D. BEN-DAK \\ Institute for Intersocietal Relations, Washington, D.C., and Department of Sociology, University of \\ Michigan
}

and EDWARD E. AZAR

Department of Political Science, University of North Carolina, Chapel Hill

Arab-Israeli relations have not figured prominently in The Journal of Conflict Resolution. Only a few contributions have focused directly on the conflict, including one review article (Ben-Dak, 1970) and scattered empirical studies (Blechman, 1966; Harary, 1961; Graber, 1969). A few articles elucidating research methodologies have demonstrated some interesting applications to the Middle East (e.g. Brecher, Steinberg, and Stein, 1969), but the dearth of articles in $J C R$ reflects the general intellectual drought affecting the growth of a "polemology" in the Arab-Israeli context-it mirrors the almost complete lack of empirical investigations relating conflict diagnosis and management to different levels and different areas of life in Israel and the Arab world (for comparison see Boulding, 1968).

The present collection is a modest attempt to rectify this situation. It was conceived when the editors were directing mutually responsive projects at the University of Michigan's Center for Research on Conflict Resolution and at Michigan State University in 1968-69. For several reasons the climate in 1970-71 had become moderately encouraging to the dissemination of research dif- ferent from the customary disappointments (see Ben-Dak, 1970).

First, materials produced more recently in the Arab world indicate a relatively fresh and growing systematization with respect to study of the confrontation. Collections of data from Israeli, Arab, and Western sources and summaries of trends have become an important item in Middle East research products in the Arabic language. These started most ambitiously with the Palestinian Movement Yearbooks and recently added the Journal of Palestine Studies (in English). Such endeavors (e.g. at the Institute for Palestine Studies and Kuwait University) are far from impartial and certainly serve a political purpose. However they approximate in direction, though not yet in quality, the veteran Middle East Record (produced by the Shiloah Center for Middle Eastern and African Studies) and the New East chronologies (in Hebrew at Jerusalem). This represents an important change from our viewpoint, because it paves the way for the use of a more rigorous data base and for agreement about the definition of series of events. These two factors heighten the probability for similar interpretations of 
events and thus for agreement on both the causes and consequences of them. Hopefully this may be true for independent judgments of Arabs and Israelis, since it has been of benefit to events data analysis of different regional conflicts done in the United States. Four articles here are a direct demonstration of what can be done with events data analysis in Arab-Israeli relations (i.e., Azar; Blechman; Burrowes and Muzzio; and Wilkenfeld, Lussier, and Tahtinen).

A second development in Middle East research, albeit slower than the first one, is the growing acceptance of differently flavored opinions and new viewpoints. An evaluation of Arab Studies and of the wellcirculated International Problems (the Israeli Institute for International Affairs, Tel Aviv) can testify to this effect. Some excellent Israeli expositions (e.g. Avineri, 1971) or any of the Institute for Palestine Studies' fledgling monographs denote more awareness of the unextraordinary, if not normal, views of "the other party." That in itself is becoming one of the most positive offsprings of research on the 1967 war. The same can be said about the veteran New Outlook (Tel Aviv) and the promising New Middle East (London).

Also the different levels of analysis that appear in use represent an ever-widening scope for the understanding of Arab-Israeli relations. This is shown in the increased work of interpersonal human relations scholars such as Prothro of the American University of Beirut (see review in Beit-Hallahmi's contribution); in more scholars approaching the confrontation interaction as a subordinate field in the foreign policy of the powers (e.g., Brecher, 1972, which reflects work currently being pursued at the Hebrew University of Jerusalem) and in the work on the Arab-Israeli conflict incorporating interaction with other regions (e.g. Mushkat's work on Africa at Tel Aviv University).

In comparison US parallels have been trailing behind in all of these respects. Thus intellectual organs like the New York Review of Books occasionally publish the views of political thinkers such as Noam Chomsky, but have never devoted much space to the Middle East (see Anonymous, 1972). The minority of journals that do print more articles about the Middle East, such as Commentary, share a rather limited number of perspectives with their audience. The more documented work has been dominated by articles about the USSR's involvement in the Middle East (see Curtis, 1971; Forsythe, 1971; Wolfe, 1970).

In order to supplement the material typically found in these mainstream publications, we have intentionally included more diversified approaches and levels of analysis in this collection. Guided by this disposition and the sincere wish to contribute to scientific knowledge of the conflict and of its potential for resolution, we chose to gear this issue toward three goals:

(a) to reflect the state of research that could be of interest to both US and Middle East researchers;

(b) to show examples of reflective empirically-oriented research that might illuminate future research directions of mutual appeal to West and East; and

(c) to present new viewpoints on courses of action or on methods pertinent to the evaluation of the positive and negative aspects of such action.

Contributions are arranged according to time perspective. Two start in 1949, cover the whole period through 1967 (Wilkenfeld, Lussier, and Tahtinen) and 1969 (Blechman), and deal with most of the members of the conflict system. The next two articles (Azar and Siverson) deal with actors involved in the 1956 campaign. In each of the first two pairs of articles, the authors use different variables and different categories of "events" to assess over time "what happened" in behavior exchanges be- 
tween Arabs, Israelis, and some foreign actors. The next two articles deal with the 1967 war. While Burrowes introduces the immediate antecedents of the war, Ibrahim measures its effect on a certain Arab population residing in the United States. Hofman also utilizes an attitude study, but at a later point-1971-and on a mixed population of Arab and Jewish students in Israel. The assessment of the current situation and of proposed future steps is discussed by the last three contributors. Dowty draws on expectations and nonexpectations from guarantees; Beit-Hallahmi reviews psychosocial work; and Ben-Dak reflects upon research that could be valuable in assessing peace prospects.

On the whole we chose articles with a nomothetic approach, ones that we felt represented an improvement over previous attempts, and ones that were acceptable to us and to a few readers both from the standpoint of scientific research and in their apparent impartiality. ${ }^{1}$

Since we are at the point of publishing

\footnotetext{
'We have subjected the articles to a relatively tough screening, and most of them have been rewritten according to the aforementioned guidelines. In addition to scholars in the Arab world and in Israel, we thought that the best persons to expose this research to were the practitioners in the different foreign services. Thus we referred most articles (including several that we cannot publish here) for "judgment" by diplomatic officials stationed in the United States, and in some cases senior practitioners in Israel and the Arab countries. We would like to express here both our gratitude to them for conveying valid and helpful criticisms-and our hope that some of the ideas presented here have already been useful for a better comprehension of the Arab-Israeli conflict.

In addition to our contributors, the Editorial Board, and regular Associate Editors of the journal, Clinton Fink, Muhammed Shaalan, and $\mathrm{M}$. Cherif Bassiouni have aided us tremendously. We are also deeply indebted to the following persons who have read manuscripts or in other ways helped us:
}

more work in these directions (e.g. Azar and Ben-Dak, 1972; Ben-Dak, 1972; and BenDak and Gross, 1972), we would welcome any comments or ideas from people who share our concern or interests in this area. As anyone seriously researching peace in the Middle East, we obviously look for challenges. Insha-Allah!

\section{REFERENCES}

Anonymous. "New York Review of Books" Middle Eastern policy, Esquire, 1972, (April), 115.

Avineri, Schlomo (ed.). Israel and the Palestinians. New York: St. Martin's Press, 1971.

Azar, Edward E., and Joseph D. Ben-Dak (eds.). International Interaction: Theory and Practice

1. Charny (American Orthopsychiatric Association);

E. Parris, R. Van-Atta, H. Yahr (American University, Washington, D.C.);

W. Clemens (Boston University);

P. Peachey, E. El-Ahwal, S. Kelly (Catholic University of America);

J. Beshai (Dixmont State Hospital);

T. Fogarty (Georgetown University);

R. Strassoldo (Instituto di Sociologia Internazionale, Gorizia);

N. Choucri (Massachusetts Institute of Techno$\log y)$;

P. R. Abramson, P. Conn (Michigan State University);

F. Barnaby (Stockholm International Peace Research Institute);

W. Gutteridge (University of Aston);

G. Goriely (Université Libre de Bruxelles);

U. Ben-Zion (University of Chicago);

M. Bonham (University of California, Berkeley);

M. Oakes, G. Shure (University of California, Los Angeles);

F. Attina (Universita degli Studi, Firenze);

B. Landheer (University of Grönigen);

F. Perlmutter (University of Maryland);

D. Gutmann, M. Magzoub, M. Mihalka (University of Michigan);

D. Bobrow (University of Minnesota);

J. Galtung, D. Heradstveit (University of Oslo);

R. W. Cottam, J. Laulicht (University of Pittsburgh);

L. Weelerman (University of Texas);

B. Tellia (Universita degli Studi, Trieste); and J. Milstein (Yale University). 
of Events Analysis. New York: Gordon and Breach, 1972 (forthcoming).

Ben-Dak, Joseph D. Time for reorientation: a review of recent research on the Arab-Israeli conflict, Journal of Conflict Resolution, 1970, 14 (1, March), 101-12.

(ed.). International Conflicts: The Methodology of Their Assessment. New York: Gordon and Breach, 1972 (in press).

and Feliks Gross (eds.). The Study of Border Regions. Gorizia, Italy: Institute of International Sociology, 1972, (forthcoming).

Blechman, Barry $M$. The quantitative evaluation of foreign policy alternatives: Sinai, 1956, Journal of Conflict Resolution, 1966, 10 (4, Dec.), 408-26.

Boulding, Kenneth. Preface to a special issue, Journal of Conflict Resolution, 1968, 12 (4, Dec.), 409-11.

Brecher, Michael. The Foreign Policy System of Israel: Settings, Images, Process. New Haven, Conn.: Yale University Press, 1972. and Janice Stein. Image and advocacy in foreign policy: Israel. In J.D. Ben-Dak (ed.), International Conflicts: The Methodology of
Their Assessment. New York: Gordon and Breach, 1972 (in press).

Blema Steinberg, and Janice Stein. A framework for research on foreign policy behavior, Journal of Conflict Resolution, 1969, 13 (1, March), 75-101.

Curtis, Michael. Soviet-American relations and the Middle East crisis, ORBIS, 1971, 15 (Spring), 403-27.

Dishon, Daniel (ed.). Middle East Record, 1967. Jerusalem: Israel University Press, 1971.

Forsythe, David P. The Soviets and the ArabIsraeli conflict, World Affairs, 1971, 135 (Fall), $132-42$.

Graber, Doris A. Perceptions of Middle East conflict in the UN, 1953-1965, Journal of Conflict Resolution, 1969, 13 (4, Dec.), 454-84.

Harary, Frank. A structural analysis of the situation in the Middle East in 1956, Journal of Conflict Resolution, 1961, 5 (2, June), 167-78.

International Problems. Tel Aviv: Israeli Institute for International Relations.

Wolfe, Thomas W. Soviet goals and policies in the Middle East. Santa Monica, Calif.: RAND Corporation Paper P-4472, 1970. 